\title{
Busy doing nothing: why politicians implement inefficient policies
}

\author{
Anders Gustafsson $^{1,2}$ (i) \\ Published online: 31 May 2019 \\ (c) The Author(s) 2019
}

\begin{abstract}
A substantial body of literature suggests that politicians are blocked from implementing efficient reforms that solve substantial problems because of special interest groups or budget constraints. Despite the existing mechanisms that block potentially efficient reforms, real-world data show that a large number of new programs and policies are implemented every year in developed countries. These policies are often selective and considered to be fairly inefficient by ex post evaluation, and they tend to be small in size and scope. With this background, this paper studies the reasons why a rational politician would implement an inefficient public policy that is intended to obfuscate the difficulties in achieving reforms. The paper uses a simple competence signaling model that suggests that if an effective reform is impossible, engaging in strategic obfuscation through an inefficient program increases the probability of winning a re-election compared to doing nothing at all. This is because an inefficient reform does not lead voters to believe that the politician is incompetent, which a lack of action risks doing. Intentional inefficiency aiming to obfuscate the difficulty of efficient reforms can therefore complement the previous theories' explanations of political failure.
\end{abstract}

Keywords Special interest groups $\cdot$ Reforms $\cdot$ Inefficiency $\cdot$ Strategic obfuscation

JEL Classification P16 $\cdot \mathrm{H} 11 \cdot \mathrm{D} 72 \cdot \mathrm{L} 82$

Something must be done, this is something, therefore we must do it. Sir Humphrey Appleby - Yes Prime Minister (1988)

Anders Gustafsson

anders.gustafsson@ratio.se

1 Jönköping International Business School, Box 1026, 55111 Jönköping, Sweden

2 Ratio Institute, Box 3203, 10364 Stockholm, Sweden 


\section{Introduction}

In most countries, significant amounts of public money are spent on active labor market programs, subsidies to private firms to increase innovation, and similar programs. An overview of evaluations of various selective support programs suggests that these programs are often found to be inefficient by ex-post evaluation. In their conclusions, most evaluation papers analyzing such programs assume that these programs were intended to be efficient but for some reason did not succeed. The lack of success is therefore attributed to a mistake or simply incompetence rather than pointing at the design of the program as an explanation of lack of success.

However, it might be the case that these programs were not designed to succeed in the first place. Due to political constraints, many economic problems are not easy or popular to address. The logic behind the difficulty of achieving efficient reforms is captured nicely in a quote of Jean-Claude Juncker, who, while working as the Prime Minister of Luxembourg, said "We all know what to do, we just don't know how to get re-elected after we've done it."1 A lack of action from a politician could, however, be interpreted as a lack of competence by the voters if voters believe that a competent politician will be skilled in solving problems and crafting efficient policies. This creates a dilemma for politicians who cannot implement policies that are efficient nor abstain from action.

This paper presents a simple competence signaling model of why a politician should introduce a non-rent-seeking inefficient public policy program as a solution to this dilemma. The model shows that a rational politician can benefit from implementing an inefficient policy when voters have imperfect information regarding the efficiency of the implemented policy but will have information if the politician does nothing at all. The aim is to provide an explanation for the inefficient policies that include neither direct rent transfer nor simple mistakes by politicians, which has been lacking in the literature to date. The model describes how a politician might improve her re-election chances by implementing programs that neither voters nor special interest groups want to see implemented and do not transfer resources to any one in particular. This is due to the action itself signaling competence to the voters, thus increasing their confidence in the politician, even if the reforms and programs are not worthwhile (Hodler et al. 2010; Spiegler 2013; Patty 2016). While an ample body of literature has explained inefficiencies due to e.g. rent-seeking, this paper suggests that the need to "do something" can be a source of inefficiency by itself since "doing nothing" is seldom a good idea for a politician that wants to be re-elected.

${ }^{1}$ The Economist (2007) "The Quest for Prosperity”, March 15th. 


\section{Political action, competence and efficient policies}

There are several reasons why it is difficult for a politician to implement a reform without suffering major political setbacks. Since small and well-defined special interest groups (SIGs) are more skilled in solving collective action problems, it is easier for them to form a coalition and use it to affect policy in their favor and preventing politicians from implementing policies that removes their privileges (Olson 1965).

In addition to opposition by SIGs, reforms can be too expensive for politicians who face binding budget constraints and lack the possibility of spending their way out of problems. Since many countries are fairly close to the Laffer curve peak, it might also be impossible to raise more revenue via taxation (Lundberg 2017). Even in countries that have ample financial resources, problems such as low economic growth might be too difficult to simply spend their way out of.

From the literature on the difficulties of implementing reforms, one might therefore get the impression that politicians often are not doing anything at all (Fernandez and Rodrik 1991; Howitt and Wintrobe 1995). Indeed, according to Friedman and Friedman (1985), there is a "tyranny of the status quo" that prevents change. However, inaction is seldom the case in practice. Countless reforms, programs, and ideas are tried out every year by governments around the world. Given the problems involved in achieving effective reforms, it is difficult to understand why there is such a large amount of political activity. Often, ex post evaluations suggest that these programs and policies are inefficient or too small to make a difference, thus making their nature even more interesting to study. One reason for the existence of such inefficient policies might be that they are designed to obfuscate the political dilemma of voters' demand for action combined with the difficulties associated with implementing effective reforms.

Why can politicians not simply admit that they do not have an effective answer to the problem in which voters are interested? If voters forms their opinion off the competence depending on how many actions they take against problems that the voters experience, a lack of action could be interpreted as a lack of competence. Political action therefore becomes a signal of competence, with more action being interpreted as higher competence. Since voters have limited information regarding the quality of their politicians, making their judgement on their perceived competence is a reasonable proxy (Lupia and McCubbins 1998; Congleton 2007).

Voters might of course more than just the politicians competence, such as their personal charisma, leadership skills or caring nature (Congleton and Zhang 2013). While correct, this paper follows the previous political signaling literature that focuses on electing a competent as the main objective for voters. In e.g. macroeconomics, there has been a long use of competence signaling models in which a politician signals her competence via boosting the economy in the year before an election by, e.g. cutting interest rates or increasing deficit spending (Rogoff 1990; Alesina et al. 1997).

It should also be noted that the institutional setting determines political action and inaction. In parliamentary systems, the ruling governments often have the 
ability to ensure that their legislation is implemented. This is vastly different than in e.g. the U.S. system, where the president might belong to a different party than the majority in the Congress which in turn affects both the organization of politics as well as the strategies for signaling competence and action. (Weingast and Marshall 1988; Krehbiel 2004). Likewise, in a more direct democracy system like the Swiss, different strategies might be used by politicians who would like to implement reforms compared to countries without elements of direct democracy (Kirchgässner 2008). These differences are not further developed in this paper but left for further research and the model presented below assumes that the ruling politicians are free to implement their policies.

\section{A model for the implementation of inefficient policies}

One version of a competence signaling model is developed by Dow and Gorton (1997), but focuses on the financial industry rather than politics. In their model, portfolio managers trade both to increase profits and to show their customers that portfolio managers are actively doing something that justifies their fees. Since the customers do not have perfect information, they cannot distinguish between efficient trading and PR-driven trading. More specifically, they cannot determine if a manager has not traded because she has not found any worthy deals (actively doing nothing), or if she is shirking (simply doing nothing). Traders will, therefore, create noise trades (so-called churning) to appear busy, although in practice they are doing nothing worthwhile. Another relevant competence signaling model is found in Dur (2001), which studies why politicians stick with inefficient decisions; however, it reverses the perspective and examines the implementation instead. In that model, a politician who removes a policy that she ex post determines to be inefficient risks sending a signal to the voters that she is incompetent. Rather than abolishing a bad policy and signaling that she is incompetent, a politician might prefer to let an inefficient policy remain in place.

Just like the customer of a portfolio manager, voters might also interpret a lack of action from their politician as a lack of competence. As voters have imperfect information on the politicians' policy options, voters remain unaware if reforms are blocked by SIGs, budget constraints or other problems. ${ }^{2}$ While there can be justified reasons for not implementing a policy, not doing so might make them look incompetent in the eyes of voters. ${ }^{3}$

\footnotetext{
2 This assumption is demanding, but empirical studies have shown that most voters have limited information on the efficiency of policies (Caplan 2011) or budget constraints (Beetsma and Debrun 2016).

${ }^{3}$ The division of political decisions into efficient and inefficient policies is slightly problematic. After all, policies involve not only efficiency but also ideology and preferences. In other words, one person's efficient reform might be another person's inefficient policy. Following the models of, e.g., Besley and Coate (1998), Dur (2001) and Battaglini and Coate (2007), it is possible to describe certain policies as political failures and, therefore, create a benchmark of efficient reforms. For example, a program intended to lower unemployment could be considered efficient if it is able to achieve this goal in a costefficient way. This is the standard notion of efficiency used in most evaluation studies in labor, industrial organization, development and international economics.
} 


\subsection{Model setup}

This section presents a competence signaling model where a lack of political action is interpreted by the voters as a lack of competence. Competent politicians are more likely to be able to implement reforms that solves the issues that voters care about than an incompetent, due to their greater ability to solve problems and craft policy. Therefore, a lack of action might be interpreted by the voters as a lack of competence amongst the politicians.

A politician that is incapable of delivering a reform (due to lack of skill or the problem being too difficult to solve) therefore have an incentive to implement a policy regardless of their efficiency, in order for her not to be viewed as incompetent by the voter. It is important to note that the model is from the voters perspective and the voters do not have full information on why the politician does not choose to implement a policy or not. They can therefore not distinguish between a lack of action due to the difficulties in creating policy or a lack of action due to a lack of competence. This creates similar incentives for the politician to be more active than necessary, as for the portfolio manager in the model by Dow and Gorton (1997).

The relevant actors in the model are politicians and voters. The incumbent politicians are facing an election and need to convince voters that the incumbents are better than their opponents. Voters are interested in electing competent politicians who can solve the problems of voters' concern, e.g., provision of public goods. The suggested model has two time periods. In the first period, nature determines the quality of the politician, and politicians choose the type of policy to pursue: preserving the status quo or implementing a reform. After the politicians have made their choice, their actions are scrutinized by voters. Having received this information, voters choose for whom to vote. Voters have perfect information regarding whether a politician has implemented a policy but do not have perfect information about whether the policy is efficient. After voters have cast their votes, the incumbent is either elected to or ousted from office, and the world ends.

The incumbent politician has a utility function with two components:

$$
\begin{gathered}
U^{H}=(V-(c-k)+b X) \\
U^{L}=(V-c+b X)
\end{gathered}
$$

where $V$ the social welfare of the project and is uniformly distributed in $[0,1]$. The social cost of implementing the project is $c$ for the incompetent politician and $c-k$ for the competent politician, reflecting the competent politicians better skill in implementing policy and solving problems. $X$ is the ego-rent that a politician receives from being in office depending on whether they are reelected $(b=1)$ or ejected from office $(b=0)$. Incumbent politicians have two different options. They can pursue reforms or do nothing by keeping the status quo. Each option has a different impact on their chances of being reelected since it affects the voters' beliefs about the politicians' competence. Since the incumbent cares about both the social value of their project and the ego-rent from being in office, the incumbent's choice will be based on what increases both the social surplus and their reelection chances. 
The realized value of $V$ is higher for a competent politician than that for an incompetent one due to the lower social cost of $c-k$ compared to $c$, where $c>k>0$. In other words, a politician of high competence is more skilled at solving problems and implementing efficient reforms than a politician of low competence. This assumption is in line with empirical observations that competent politicians are indeed more skilled in delivering positive outcomes than incompetent ones (Besley 2005; Gagliarducci and Nannicini 2013).

The incumbent can be either of high or low competence. The probability that the incumbent is of high competence is $\pi$, so the probability that she is and of low competence is $1-\pi$. Voters have information regarding $\pi$ and the incumbent's utility function, but they know neither the realization of the incumbent's competence nor the value of $V$. Voters' beliefs about the competence of the incumbent are therefore $\pi^{I}$ before the implementation of the policy and are $\hat{\pi}_{R}^{I}$ or $\hat{\pi}_{N}^{I}$ afterwards, depending on whether the incumbent implemented a reform or did nothing. In an election, the incumbent will face an opponent; the voters' belief regarding the competence $\pi^{O}$ of the latter is randomly drawn from a cumulative distribution function $G(\cdot):[0,1] \rightarrow[0,1]$ just before the election. Voters will therefore elect the opponent rather than the incumbent if they believe that $\pi^{O}>\hat{\pi}^{I}$, and vice versa.

For a given policy issue, the timeline of the model is as follows:

1. Nature determines the quality of the incumbent as competent or incompetent, with probability $\pi$ or $1-\pi$, respectively. Nature also determines the social value, $V$, of the reform.

2. The incumbent observes if they are competent or incompetent and realized the value of the reform, $V$ and the attached $\operatorname{costs}, c$ and $k$. Based on this information, the incumbent decides which policy to pursue, i.e., to implement a reform or to do nothing.

3. Voters observe the incumbent's utility function and the chosen action, and they revise their prior probabilities of the incumbent's competence. They then participate in the election, and the incumbent is either reelected or ejected from office.

4. The game ends.

\subsection{Policy outcomes}

Solving the model for each Perfect Bayesian Equilibrium (PBE) requires calculating which candidate the voters believe is the most competent, given the action of the incumbent (Selten 1965; Kreps and Wilson 1982; Cho and Kreps 1987). Since the voters' decision is based on the incumbents' action and the incumbent's action depends on her utility function, three different cases will be considered. In short, an incumbent who is only concerned with what is best for the society will never implement a policy that she does not believe to be good for the society. Hence, this incumbent is less likely to implement policies, especially if the incumbent is incompetent. However, since doing nothing increases the voters' belief that the incumbent is incompetent, ceteris paribus, this decision lowers the reelection chances. An incumbent who cares only about their ego-rent from being in office will therefore always 
implement policies, even if they are unlikely to be successful, since doing nothing would hurt the incumbent's reelection chances.

\subsection{Equilibrium with benevolent politicians}

If voters know that the incumbent will never implement a policy that she believes has a negative cost-benefit value, despite this having a negative effect on her reelection chances, that is, if $X=0$, it must be the case that the policy satisfies

for a competent incumbent and

$$
V>c-k
$$

$$
V>c
$$

for an incompetent one. Since the incumbent knows the realization of $V$ before implementing the policy, there is no need to calculate the expected value from the incumbent's point of view. For voters, however, the probability that the project is worthwhile is

$$
p(V>c-k)
$$

or

$$
p(V>c)
$$

for competent and incompetent incumbents, respectively. The probabilities of the politician being competent or incompetent, conditional on them implementing a project, will henceforth be denoted by $p(k)$ and $p(0)$.

If the incumbent implements a reform, then voters update their prior beliefs about the incumbent's competence based on Bayes' theorem, which in this case means that

$$
\hat{\pi}_{R}^{I}=\frac{\pi^{I} p(k)}{\pi^{I} p(k)+\left(1-\pi^{I}\right) p(0)}
$$

If she instead does nothing, voters believe that her competence is

$$
\hat{\pi}_{N}^{I}=\frac{\pi^{I}(1-p(k))}{\pi^{I}(1-p(k))+\left(1-\pi^{I}\right)(1-p(0))}
$$

Since $p(k)>p(0), \hat{\pi}_{R}^{I}>\pi>\hat{\pi}_{N}^{I}$; the incumbent increases the voters' belief in her competence if she implements a policy. Note that voters form their beliefs based on the politicians' action rather than the outcome of the action. Given that voters believe that the incumbent will not implement a project that is not worthwhile, this means that if the (competent) incumbent does not implement a project, it must be the case that social benefits from the reform are lower than the social costs,

$$
V<c-k
$$

In the extreme case of $X=0$, a politician will never implement a project that does not have a positive social value since she does not care about her reelection changes but only about the public welfare. 


\subsection{Equilibrium with non-benevolent politicians}

The assumption of completely benevolent politicians is perhaps too extreme. The most interesting cases are therefore when a politician who cares about both the social effects of a policy and her own ego-rent implements a reform with a negative expected value to increase her reelection chances. When $X>0$, politicians care about both the effects of their policies and their reelection chances. The opponent is drawn from the $\operatorname{CDF} G(\cdot)$, and the drawn competence is what the incumbent will compete against in the election. Putting all of this together, we can see that the probability of a reform being implemented depends on the realized value of $V$, the politicians' own competence and how the reform will affect their reelection chances. The probability that a reform will be implemented can therefore be expressed as a function that depends both on their competence and the value of $V$, and it can be denoted $p(k, x)$ and $p(0, x)$ for the competent and incompetent incumbents, respectively. A competent politician will implement a reform if its value is positive and it increases her reelection chances, i.e., if

$$
p(k, x)=p\left[V>(c-k)-X\left(G\left(\hat{\pi}_{R}^{I}\right)-G\left(\hat{\pi}_{N}^{I}\right)\right)\right]
$$

which becomes

$$
p(k, x)=1-\left(c-k-X\left(G\left(\hat{\pi}_{R}^{l}\right)-G\left(\hat{\pi}_{N}^{l}\right)\right)\right)
$$

since $V$ is uniformly distributed.

An incompetent politician, instead, will implement a reform if

$$
\begin{gathered}
p(0, x)=p\left[V>(c)-X\left(G\left(\hat{\pi}_{R}^{I}\right)-G\left(\hat{\pi}_{N}^{I}\right)\right)\right] \\
p(0, x)=1-\left(c-X\left(G\left(\hat{\pi}_{R}^{I}\right)-G\left(\hat{\pi}_{N}^{I}\right)\right)\right)
\end{gathered}
$$

where the first term is the social value of the project given the politician's competence and the second term is the likelihood that the politician will win the election and continue enjoying the ego-rent. Inserting 6 and 8 into 3 and 4 results in two large equations that are fully presented in the appendix. These two equations need to be solved simultaneously. There is no simple algebraic solution, but for given parameter values, the equations can be solved numerically. For simplicity, assume $c=0.5, k=0.2$ and $\pi=0.5$. In this case, we can plot how the incumbent's ego-rent $X$ affects the probability of implementing a reform, as shown in Fig. 1.

The figures show the difference in the probability of implementing a reform, with the competent politicians shown as the solid line and the incompetent shown as the dashed line. The bonus $k$ that a competent politician has is clearly shown by the gap between the lines. There is an interesting jump in the function as $\mathrm{X}$ increases. When it becomes more likely that an incumbent will implement a reform, not implementing a reform has more negative effects on the reelection chances. As $X$ approaches 1, the incumbent will always implement a reform, regardless of whether is worthwhile, since not doing so would have an excessively large negative effect on the incumbent's reelection chances. At a sufficiently high value of the ego-rent, the incumbent is busy doing nothing, that is, implementing 


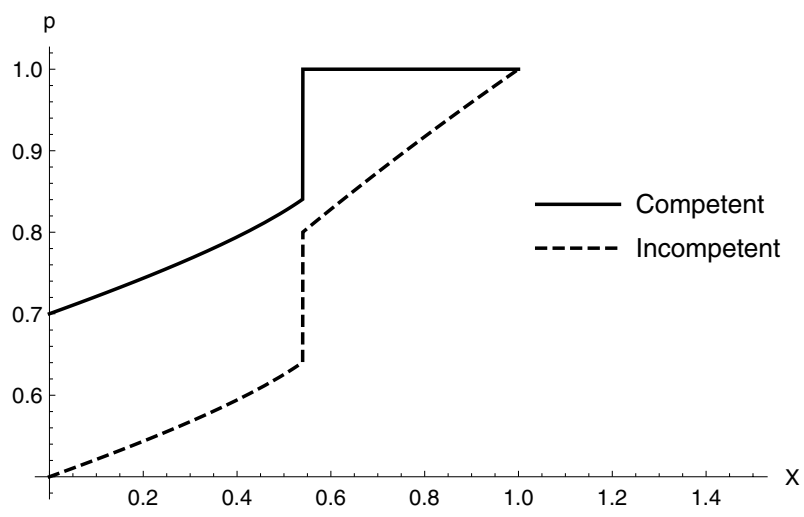

Fig. 1 Probability of implementing a reform. The difference in the willingness to implement a policy between a competent (solid line) and an incompetent (dashed line) incumbent depending on their egorents when there are equal numbers of competent and incompetent politicians

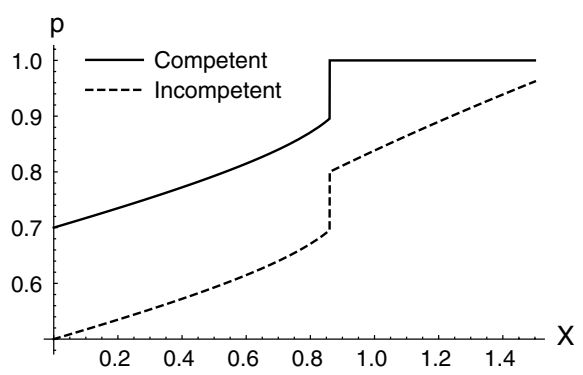

(a)

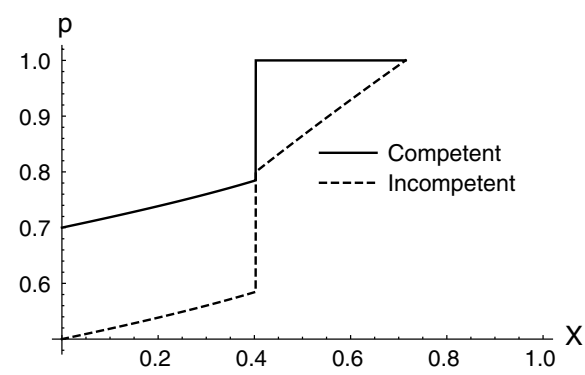

(b)

Fig. 2 a Incompetent politicians are less typical. b Incompetent politicians are more typical

inefficient reforms to avoid a loss in the election. The extreme case where politicians only care about their ego-rent is presented in the next section.

If competent politicians are less typical, that is, if $\pi=0.3$, the equilibrium becomes somewhat different, as shown in Fig. 2a. Since it is less typical to be competent, the penalty for inactivity becomes less severe. On the other hand, if competent politicians are typical, i.e., if $\pi=0.7$, as shown in Fig. $2 b$, it becomes difficult for a politician to not implement a policy. Since competent politicians are typical, inactivity becomes a strong signal of incompetence. While this might seem paradoxical, the effect is similar to that of job market signaling models, where a lack of education becomes more problematic when the number of educated individuals increases (Spence 1973).

\subsection{Equilibrium with completely selfish politicians}

If politicians are completely selfish, and voters know this, politicians have no incentives to not implement a policy. If voters instead believe that politicians care 
only about their ego-rents from being in office and do not care about their effects on the public, then implementing a reform would not cause them to change their beliefs about the incumbent's competence. Their prior beliefs remain identical to the updated believes on politicians' competence. Since the politician is unconcerned with the value of $V$, it is rational for her to implement a reform if the off path believes are such that

$$
X\left(G\left(\pi^{I}\right)-G\left(\hat{\pi}_{N}^{I}\right)\right)>0
$$

which is always positive. ${ }^{4}$ This represents a pooling PBE where both types of politicians "churn" out new policies, regardless of whether the policies can effectively avoid the negative effects on their reelection chances that doing nothing will produce. ${ }^{5}$ Voters will therefore not get any new information regarding the competence of the politician depending on their decisions and will therefore cast their votes based on only their priors. In this extreme case, both politicians and voters are stuck in an inefficient equilibrium with constant churning of inefficient policies that do not achieve anything, neither as policy nor as signals. Constitutional restraints on a politicians abilities to implement policies without e.g. previous cost-benefit analysis might be a way out of this equilibrium, but this possibility is left for further research.

\subsection{Discussion}

There is the large body of literature that evaluates the efficiency and effects of labor market programs, industrial policy, foreign aid and similar issues that often finds that these programs are inefficient even in otherwise efficient OECD countries (e.g., Easterly 2006; Lerner 2009). If a policy has been deemed inefficient, this strand of literature concludes that this inefficiency must be either a mistake by the policymaker or a faulty implementation. After all, why would a policymaker want to introduce or retain inefficiency, especially when the respective programs do not seem to be examples of rent-seeking? However, as pointed out by Stigler (1982): "No one could support the thesis that societies make no mistakes, especially in a magazine published in Washington, D.C., the center of the mistake industry. But to explain something by saying that it is a mistake is on the same level as explaining it by pointing to invisible spirits."

While intentional inefficiencies might seem somewhat counter-intuitive, they become less so if we consider that a politician may have a limited ability to address the problems they are faced with but do not want to admit defeat. Special interest groups can sometimes exert pressure on politicians through lobbying (Grossman and Helpman 2001). This influence often results in blocking reforms that would address the issues in which voters are interested. Reforms can also be difficult to implement due to technical challenges or binding budget constraints. The pressure created by a

\footnotetext{
${ }^{4}$ Note that voters' beliefs are $\pi^{I}$ rather than $\hat{\pi}_{R}^{I}$ since voters do not receive any additional information in this equilibrium when a politician implements a reform.

5 While there might be off-equilibrium strategies for a politician to not implement a policy, these offequilibrium strategies does not seem to be intuitive and can therefore be discarded (Cho and Kreps 1987).
} 


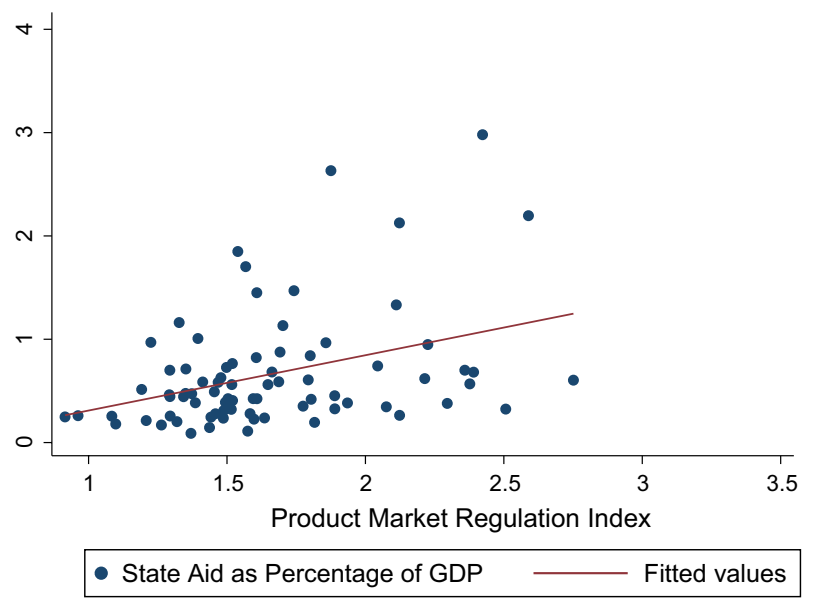

Fig. 3 Product market policies. Spending on state aid to firms as a percentage of GDP, and OECD's product market regulation index. A higher PMR score indicates a more regulated market

combination of an inability to implement reforms and a pressure from voters creates a demand for action that politicians must address. Politicians are, therefore, driven to implement programs and policies that are more or less inefficient in order to increase reelection chances. While the previous literature often suggests that preserving the status quo is a viable option for politicians, this is an unreasonable assumption in countries with a free press that gives voters the information needed to punish politicians who do nothing to solve the problems with which the public is concerned (Strömberg 2004; Snyder and Strömberg 2010).

As an example, consider the case of product market regulation that tends to reduce economic growth and generate rents for incumbent firms (Blanchard and Giavazzi 2003). Instead of removing such regulations, countries to subsidize their firms, as indicated by Fig. 3, despite the questionable efficiency of subsidies (Zúñiga-Vicente et al. 2014). ${ }^{6}$ Since removing such regulations involves a politician facing off against incumbent firms that benefit from them and might lobby for the restrictions to remain in place, subsidizing firms can be a rational policy response when voters demand reforms that increase economic growth. New firms that could prosper with less regulation do not yet exist and are therefore ineffective in lobbying (Potts et al. 2016). If voters have imperfect information on the efficiency of firm subsidies, it is likely that voters will believe that politicians are responding to the voters' demands for policies that increase economic growth.

As another example, it seems possible to reduce unemployment by reducing the minimum wage and employment protection, especially in European countries (Neumark and Wascher 2007) or removing occupational licensing in e.g. the U.S.

\footnotetext{
${ }^{6}$ Data are taken from Eurostat and OECD's online ilibrary; each dot is a country-year observation. The product market index is only available for the years 1998, 2003, 2008 and 2013. A full data description is available in the appendix. The correlation is significant at the $1 \%$ level, even when controlling for state fixed effects in a regression.
} 
(Kleiner 2000). Cutting minimum wages or reducing employment protection would, however, put politicians in direct conflict with labor market insiders, represented by trade unions or similar organizations (Lindbeck and Snower 1989). Instead of addressing the problem head on, politicians tend to, implement various training programs or offering subsidies is a way to avoid this conflict, even though the positive effects from these programs are less than clear-cut (Card et al. 2010).

An important point of this model is that doing nothing is seldom a good idea for a politician, which the following anecdote illustrates. In 1966, the Swedish Prime Minister Tage Erlander was asked on national TV what advice he would give a young couple who were looking for a place to live in Stockholm. At this time, the waiting time for an apartment was approximately 10 years, mostly due to the effects of rent control. The Prime Minister's only response was that the couple should get into the official waiting line and perhaps consider moving to some other city where the housing shortage was not as acute. The opposition was able to use Erlander's lack of a satisfactory answer to the journalists' questions in their campaign, and this is viewed as a key reason why the Social Democrats fared poorly in the local elections in that year. ${ }^{7}$ This opposition strategy, combined with the fact that Erlander was unable to remove rent control because of resistance from both the Swedish Union of Tenants (with close links to his party) and the center-right opposition, led the Social Democrats to pursue a program of massive investments in housing to neutralize the question before the election in 1968. Erlander's investment strategy was made possible by the high GDP growth and low public debt at the time (Malm Lindberg 2014). For a politician without the ability to spend her way out of the problem, as Erlander did, the need to obfuscate the problem with inefficient policies would be greater. If voters can punish a politician who does not address problems that they care about, they will do so. An alternative strategy must be found to resolve this dilemma. According to the model above, inefficient policies might be just that alternative.

Another important aspect of the model in this paper is that it explains not the persistence of inefficient policies but the introduction of new ones. The evaluation literature regarding, e.g., labor market policies, assumes that once the problems of policies have been exposed, such policies will change. However, if the point of a policy is simply to divert attention away from a problem that cannot be solved, a more likely outcome might be that the program is reorganized and renamed but continues to exist. This phenomenon can therefore be viewed as a complement to the model of inefficient policy persistence suggested by Coate and Morris (1999) or Dur (2001), in which inefficient programs remain because of more direct lobbying efforts or because politicians do not want to expose themselves as incompetent by revealing that their previous effort was a failure. To sell the new inefficient policies, it might also be useful for politicians to be ambiguous about how the policy will achieve the goal the public wants (Page 1976; Alesina and Cukierman 1990). A constant flow of new inefficient policies might also be one reason for the empirical observation that politics tends to "muddle through" without any drastic change (Lindblom 1959, 1979).

\footnotetext{
7 To this day, rent control is still implemented in Sweden, although in a slightly modified form. The election in 1966 was a local election and the first chamber election, and the poor result for the Social Democrats did not lead to a change in government at the state level.
} 
Other models of inefficient redistribution have focused on beneficial transfers to special interests (Coate and Morris 1995; Acemoglu and Verdier 2000; Acemoglu and Robinson 2001). It is therefore important to stress that no group of voters or politicians has a preference for inefficient policies. These policies do not transfer any resources to any group nor create any surpluses, so they are therefore always Pareto dominated by the status quo, which at least does not waste resources. In contrast, the creation of inefficient policies is the logical result of the combination of voters with imperfect information, the difficulties of effective reforms and ego-rents that politicians derive from being in office.

\section{Conclusions}

According to the model in this paper, an inefficient program can often be the rational solution for a politician who is concerned about her reelection chances and is unable to implement difficult reforms and thus risks upsetting voters by not addressing issues that matter to them. While this model shares similarities with models presented in the existing literature on political failures and inefficient transfers, the major difference is the lack of a direct benefit of these programs. While it seems almost paradoxical that resources should be spent on programs and policies that no one directly benefits from, it becomes less paradoxical when one considers the dilemma of reforms. This differs from previous theories that have focused on the effects of transferred resources and their recipients, such as those presented by e.g. Becker (1983), Dixit (1998) or Acemoglu and Robinson (2001).

A goal of the paper is to offer a more formal definition of the notion that politicians "have to do something". While this phrase is often used in public debates, it is has received too little attention in academia. Hopefully, the model and stylized facts presented in this paper regarding practical aspects of policies will be a useful scaffolding for more detailed models. In this model, politicians are trapped between a rock and a hard place. With imperfect monitoring, it is sometimes better to appear to be busy creating policies that, in reality, achieve nothing, to avoid being accused of a lack of effort (Weaver 1986). When voters do not have perfect information about outcomes, the stated intentions of inefficient policies become an important tool for a rational politician if she wants to obfuscate a problem that is hard to solve.

The model might explain why even well-functioning states implement inefficient policies, such as inefficient labor market programs. If efficient reforms are blocked by, e.g., powerful unions and the voters' concern with unemployment is too great to leave the issue unaddressed, only one option remains. An inefficient yet hard to evaluate program becomes the best option for a politician who wants to be reelected. The incentives to appear busy by churning policies can be more relevant to politicians than being efficient. The more typical competent politicians are, the more important it becomes for politicians to implement policies in order for them to not appear to be incompetent. A high percentage of competent politicians can, somewhat unintuitively, lead to more inefficient policies. Economists and other social scientists who evaluate programs and policies and observe such programs and policies to not achieve their stated goals should not assume that these inefficiencies are mere 
mistakes; instead, they should investigate whether such programs and policies are intended to "cover up" the existing problems.

One assumption in this paper is that politicians have better information on the expected value of a reform than voters do. While there seems to be plenty of evidence supporting this assumption, further studies of how voters receive and process information are needed. In particular, the role the media or political opposition can play in preventing an inefficient equilibrium from being an effective strategy is an interesting question.

Similar to the unproductive, as opposed to destructive, entrepreneurs in Baumol (1990), inefficient policies are perhaps less problematic than pure corruption or rentseeking, in the sense that they do not undermine the foundations of democracy in the same way. However, since the programs are a genuine waste of resources, and only exist to divert attention, their existence is still problematic. If politicians were able to explain why they decided to do nothing without damaging their reelection chances, this would Pareto dominate their implementing inefficient policies.

Acknowledgements The author is grateful to Andreas Bergh, Pingjing Bo, Roger D. Congleton, Justus Haucap, Gustav Karreskog, Peter Leeson, Agostino Manduchi, Jaakko Merilälinen, Torsten Persson, Gustav Tinghög, and two anonymous referees; along with seminar participants at Södertörn University College, Jönköping International Business School, the Mercatus Center at George Mason University, the Ratio Institute, the 2016 SWEGPEC-conference, the 2017 Public Choice Society Conference and the 2017 Baugh-Ratio Colloquium for Young Social Scientists for helpful comments.

Open Access This article is distributed under the terms of the Creative Commons Attribution 4.0 International License (http://creativecommons.org/licenses/by/4.0/), which permits unrestricted use, distribution, and reproduction in any medium, provided you give appropriate credit to the original author(s) and the source, provide a link to the Creative Commons license, and indicate if changes were made.

\section{Appendix}

\section{Additional calculations}

Below are the full equations for how voters update their beliefs regarding a politician's competence. Implementing a reform leads voters to update their priors according to

$$
\hat{\pi}_{R}^{I}=\frac{\pi^{I}\left(1-\left(c-k-X\left(G\left(\hat{\pi}_{R}^{I}\right)-G\left(\hat{\pi}_{N}^{I}\right)\right)\right)\right.}{\pi^{I}\left(1-\left(c-k-X\left(G\left(\hat{\pi}_{R}^{I}\right)\right)-G\left(\hat{\pi}_{N}^{I}\right)\right)\right)+\left(1-\pi^{I}\right)\left(1-\left(c-X\left(G\left(\hat{\pi}_{R}^{I}\right)-G\left(\hat{\pi}_{N}^{I}\right)\right)\right)\right.}
$$

whereas doing nothing leads voters to believe that the politician's competence is

$$
\hat{\pi}_{N}^{I}=\frac{\pi^{I}\left(1-\left(1-\left(c-k-X\left(G\left(\hat{\pi}_{R}^{I}\right)-G\left(\hat{\pi}_{N}^{I}\right)\right)\right)\right.\right.}{\pi^{I}\left(1-\left(1-\left(c-k-X\left(G\left(\hat{\pi}_{R}^{I}\right)\right)-G\left(\hat{\pi}_{N}^{I}\right)\right)\right)+\left(1-\pi^{I}\right)\left(1-\left(c-X\left(G\left(\hat{\pi}_{R}^{I}\right)-G\left(\hat{\pi}_{N}^{I}\right)\right)\right)\right.\right.}
$$

\section{Statistics}

The table below presents the data shown in Fig. 3 (Table 1). 
Table 1 Product market regulation and state aid to firms

\begin{tabular}{|c|c|c|c|c|}
\hline & Observations & Mean & Median & $\mathrm{SD}$ \\
\hline \multicolumn{5}{|l|}{ Austria } \\
\hline State aid as percentage of GDP & 4 & .42 & 0 & .11 \\
\hline Product market regulation index & 4 & 1.6 & 1 & .404 \\
\hline \multicolumn{5}{|l|}{ Belgium } \\
\hline State aid as percentage of GDP & 4 & .35 & 0 & .0771 \\
\hline Product market regulation index & 4 & 1.7 & 2 & .404 \\
\hline \multicolumn{5}{|l|}{ Bulgaria } \\
\hline State aid as percentage of GDP & 1 & .11 & 0 & - \\
\hline Product market regulation index & 1 & 1.6 & 2 & - \\
\hline \multicolumn{5}{|l|}{ Croatia } \\
\hline State aid as percentage of GDP & 1 & .35 & 0 & - \\
\hline Product market regulation index & 1 & 2.1 & 2 & - \\
\hline \multicolumn{5}{|l|}{ Czech Republic } \\
\hline State aid as percentage of GDP & 3 & 1.5 & 1 & 1.03 \\
\hline Product market regulation index & 3 & 1.6 & 1 & .253 \\
\hline \multicolumn{5}{|l|}{ Denmark } \\
\hline State aid as percentage of GDP & 4 & .75 & 1 & .152 \\
\hline Product market regulation index & 4 & 1.4 & 1 & .187 \\
\hline \multicolumn{5}{|l|}{ Estonia } \\
\hline State aid as percentage of GDP & 2 & .28 & 0 & .264 \\
\hline Product market regulation index & 2 & 1.3 & 1 & .0552 \\
\hline \multicolumn{5}{|l|}{ Finland } \\
\hline State aid as percentage of GDP & 4 & .48 & 0 & .15 \\
\hline Product market regulation index & 4 & 1.5 & 1 & .292 \\
\hline \multicolumn{5}{|l|}{ France } \\
\hline State aid as percentage of GDP & 4 & .52 & 1 & .11 \\
\hline Product market regulation index & 4 & 1.8 & 2 & .417 \\
\hline \multicolumn{5}{|l|}{ Germany } \\
\hline State aid as percentage of GDP & 4 & .71 & 1 & .23 \\
\hline Product market regulation index & 4 & 1.7 & 2 & .421 \\
\hline \multicolumn{5}{|l|}{ Greece } \\
\hline State aid as percentage of GDP & 4 & .75 & 1 & .496 \\
\hline Product market regulation index & 4 & 2.3 & 2 & .434 \\
\hline \multicolumn{5}{|l|}{ Hungary } \\
\hline State aid as percentage of GDP & 3 & 1.4 & 1 & .358 \\
\hline Product market regulation index & 3 & 1.7 & 2 & .406 \\
\hline \multicolumn{5}{|l|}{ Ireland } \\
\hline State aid as percentage of GDP & 4 & .55 & 0 & .292 \\
\hline Product market regulation index & 4 & 1.6 & 2 & .219 \\
\hline \multicolumn{5}{|l|}{ Italy } \\
\hline State aid as percentage of GDP & 4 & .4 & 0 & .225 \\
\hline Product market regulation index & 4 & 1.7 & 2 & .475 \\
\hline
\end{tabular}


Table 1 (continued)

\begin{tabular}{|c|c|c|c|c|}
\hline & Observations & Mean & Median & $\mathrm{SD}$ \\
\hline \multicolumn{5}{|l|}{ Latvia } \\
\hline State aid as percentage of GDP & 1 & 1.5 & 1 & - \\
\hline Product market regulation index & 1 & 1.6 & 2 & - \\
\hline \multicolumn{5}{|l|}{ Lithuania } \\
\hline State aid as percentage of GDP & 1 & .32 & 0 & - \\
\hline Product market regulation index & 1 & 1.5 & 2 & - \\
\hline \multicolumn{5}{|l|}{ Luxembourg } \\
\hline State aid as percentage of GDP & 3 & .22 & 0 & .0672 \\
\hline Product market regulation index & 3 & 1.5 & 1 & .0872 \\
\hline \multicolumn{5}{|l|}{ Malta } \\
\hline State aid as percentage of GDP & 1 & 1.7 & 2 & - \\
\hline Product market regulation index & 1 & 1.6 & 2 & - \\
\hline \multicolumn{5}{|l|}{ Netherlands } \\
\hline State aid as percentage of GDP & 4 & .24 & 0 & .0282 \\
\hline Product market regulation index & 4 & 1.3 & 1 & .434 \\
\hline \multicolumn{5}{|l|}{ Poland } \\
\hline State aid as percentage of GDP & 3 & 1.4 & 1 & 1.35 \\
\hline Product market regulation index & 3 & 2 & 2 & .388 \\
\hline \multicolumn{5}{|l|}{ Portugal } \\
\hline State aid as percentage of GDP & 4 & 1.4 & 2 & .955 \\
\hline Product market regulation index & 4 & 1.9 & 2 & .557 \\
\hline \multicolumn{5}{|l|}{ Romania } \\
\hline State aid as percentage of GDP & 1 & .59 & 1 & - \\
\hline Product market regulation index & 1 & 1.7 & 2 & - \\
\hline \multicolumn{5}{|l|}{ Slovenia } \\
\hline State aid as percentage of GDP & 2 & .79 & 1 & .48 \\
\hline Product market regulation index & 2 & 1.8 & 2 & .132 \\
\hline \multicolumn{5}{|l|}{ Spain } \\
\hline State aid as percentage of GDP & 4 & .49 & 1 & .195 \\
\hline Product market regulation index & 4 & 1.8 & 2 & .416 \\
\hline \multicolumn{5}{|l|}{ Sweden } \\
\hline State aid as percentage of GDP & 4 & .58 & 1 & .246 \\
\hline Product market regulation index & 4 & 1.6 & 2 & .179 \\
\hline \multicolumn{5}{|l|}{ United Kingdom } \\
\hline State aid as percentage of GDP & 4 & .21 & 0 & .0317 \\
\hline Product market regulation index & 4 & 1.2 & 1 & .11 \\
\hline
\end{tabular}

Product market regulation and state aid to firms in 1998-2013 


\section{References}

Acemoglu, D., \& Robinson, J. A. (2001). Inefficient redistribution. American Political Science Review, $95(3), 649$.

Acemoglu, D., \& Verdier, T. (2000). The choice between market failures and corruption. American Economic Review, 90(1), 194-211.

Alesina, A., \& Cukierman, A. (1990). The politics of ambiguity. Quarterly Journal of Economics, 105(4), 829-850.

Alesina, A., Roubini, N., \& Cohen, G. D. (1997). Political cycles and the macroeconomy. Cambridge: MIT Press.

Battaglini, M., \& Coate, S. (2007). Inefficiency in legislative policymaking: A dynamic analysis. American Economic Review, 97(1), 118-149.

Baumol, W. J. (1990). Entrepreneurship: Productive, unproductive, and destructive. Journal of Political Economy, 98(5 Part 1), 893-921.

Becker, G. S. (1983). A theory of competition among pressure groups for political influence. Quarterly Journal of Economics, 98(3), 371-400.

Beetsma, R. M., \& Debrun, X. (2016). Fiscal councils: Rationale and effectiveness. Technical report, CEPR Discussion Paper No. DP11140.

Besley, T. (2005). Political selection. Journal of Economic Perspectives, 19(3), 43-60.

Besley, T., \& Coate, S. (1998). Sources of inefficiency in a representative democracy: A dynamic analysis. American Economic Review, 88(1), 139-56.

Blanchard, O., \& Giavazzi, F. (2003). Macroeconomic effects of regulation and deregulation in goods and labor markets. Quarterly Journal of Economics, 118(3), 879-907.

Caplan, B. (2011). The myth of the rational voter: Why democracies choose bad policies. Princeton: Princeton University Press.

Card, D., Kluve, J., \& Weber, A. (2010). Active labour market policy evaluations: A meta-analysis. Economic Journal, 120(548), F452-F477.

Cho, I.-K., \& Kreps, D. M. (1987). Signaling games and stable equilibria. Quarterly Journal of Economics, 102(2), 179-221.

Coate, S., \& Morris, S. (1995). On the form of transfers to special interests. Journal of Political Economy, 103(6), 1210-1235.

Coate, S., \& Morris, S. (1999). Policy persistence. American Economic Review, 89(5), 1327-1336.

Congleton, R. D. (2007). Informational limits to democratic public policy: The jury theorem, yardstick competition, and ignorance. Public Choice, 132(3-4), 333-352.

Congleton, R. D., \& Zhang, Y. (2013). Is it all about competence? The human capital of us presidents and economic performance. Constitutional Political Economy, 24(2), 108-124.

Dixit, A. K. (1998). The making of economic policy: A transaction-cost politics perspective. Cambridge: MIT Press.

Dow, J., \& Gorton, G. (1997). Noise trading, delegated portfolio management, and economic welfare. Journal of Political Economy, 105(5), 1024-1050.

Dur, R. A. (2001). Why do policy makers stick to inefficient decisions? Public Choice, 107(3-4), 221-234.

Easterly, W. (2006). The white man's burden: Why the West's efforts to aid the rest have done so much ill and so little good. Oxford: Oxford University Press.

Fernandez, R., \& Rodrik, D. (1991). Resistance to reform: Status quo bias in the presence of individualspecific uncertainty. American Economic Review, 81(5), 1146-55.

Friedman, M., \& Friedman, R. D. (1985). Tyranny of the status quo. Boston: Houghton Mifflin Harcourt.

Gagliarducci, S., \& Nannicini, T. (2013). Do better paid politicians perform better? Disentangling incentives from selection. Journal of the European Economic Association, 11(2), 369-398.

Grossman, G. M., \& Helpman, E. (2001). Special interest politics. Cambridge: MIT Press.

Hodler, R., Loertscher, S., \& Rohner, D. (2010). Inefficient policies and incumbency advantage. Journal of Public Economics, 94(9-10), 761-767.

Howitt, P., \& Wintrobe, R. (1995). The political economy of inaction. Journal of Public Economics, 56(3), 329-353.

Kirchgässner, G. (2008). Direct democracy: Obstacle to reform? Constitutional Political Economy, 19(2), 81-93.

Kleiner, M. M. (2000). Occupational licensing. Journal of Economic Perspectives, 14(4), 189-202. 
Krehbiel, K. (2004). Legislative organization. Journal of Economic Perspectives, 18(1), 113-128.

Kreps, D. M., \& Wilson, R. (1982). Sequential equilibria. Econometrica, 50(4), 863-94.

Lerner, J. (2009). Boulevard of broken dreams: Why public efforts to boost entrepreneurship and venture capital have failed-and what to do about it. Princeton: Princeton University Press.

Lindbeck, A., \& Snower, D. J. (1989). The insider-outsider theory of employment and unemployment. Cambridge: MIT Press.

Lindblom, C. E. (1959). The science of "muddling through". Public Administration Review, 19(2), 79-88.

Lindblom, C. E. (1979). Still muddling, not yet through. Public Administration Review, 39(6), 517-526.

Lundberg, J. (2017). The Laffer curve for high incomes. Technical Report 9, Uppsala University, Department of Economics Working Paper.

Lupia, A., \& McCubbins, M. D. (1998). The democratic dilemma: Can citizens learn what they need to know? Cambridge: Cambridge University Press.

Malm Lindberg, H. (2014). Drömmen om jämlikhet : socialdemokratins radikalisering och den svenska modellens fall. Atlantis.

Neumark, D., \& Wascher, W. L. (2007). 'Minimum wages and employment', Foundations and Trends®. Microeconomics, 3(1-2), 1-182.

Olson, M. (1965). The logic of collective action: Public goods and the theory of collective action. Cambridge: Harvard University Press.

Page, B. I. (1976). The theory of political ambiguity. American Political Science Review, 70(03), $742-752$.

Patty, J. W. (2016). Signaling through obstruction. American Journal of Political Science, 60(1), 175-189.

Potts, J., Allen, D. W. \& MacDonald, T. J. (2016). Keep your friends close, your enemies closer: The case for inclusive innovation policy. Technical report, SSRN. https://ssrn.com/abstract=2836301.

Rogoff, K. (1990). Equilibrium political budget cycles. American Economic Review, 80(1), 21.

Selten, R. (1965). Spieltheoretische behandlung eines oligopolmodells mit nachfrageträgheit: Teil i: Bestimmung des dynamischen preisgleichgewichts. Zeitschrift für die gesamte Staatswissenschaft, 121(H. 2), 301-324.

Snyder, J. M, Jr., \& Strömberg, D. (2010). Press coverage and political accountability. Journal of Political Economy, 118(2), 355-408.

Spence, M. (1973). Job market signaling. The Quarterly Journal of Economics, 87(3), 355-374.

Spiegler, R. (2013). Placebo reforms. American Economic Review, 103(4), 1490-1506.

Stigler, G. J. (1982). Economists and public policy. Regulation, 6, 13.

Strömberg, D. (2004). Mass media competition, political competition, and public policy. Review of Economic Studies, 71(1), 265-284.

Weaver, R. K. (1986). The politics of blame avoidance. Journal of Public Policy, 6(04), 371-398.

Weingast, B. R., \& Marshall, W. J. (1988). The industrial organization of congress; or, why legislatures, like firms, are not organized as markets. Journal of Political Economy, 96(1), 132-163.

Zúñiga-Vicente, J. Á., Alonso-Borrego, C., Forcadell, F. J., \& Galán, J. I. (2014). Assessing the effect of public subsidies on firm R\&D investment: A survey. Journal of Economic Surveys, 28(1), 36-67.

Publisher's Note Springer Nature remains neutral with regard to jurisdictional claims in published maps and institutional affiliations. 